Research Article

\title{
Synthesis, Characterization, and In Vitro Cytotoxicity of Unsymmetrical Tetradentate Schiff Base $\mathrm{Cu}(\mathrm{II})$ and Fe(III) Complexes
}

\author{
Quang Trung Nguyen (D, Phuong Nam Pham Thi, and Van Tuyen Nguyen \\ Institute of Chemistry, Vietnam Academy of Science and Technology, 18 Hoang Quoc Viet, Cau Giay, Hanoi, Vietnam \\ Correspondence should be addressed to Quang Trung Nguyen; trungquang_cnhh@yahoo.com
}

Received 16 October 2020; Revised 13 March 2021; Accepted 16 April 2021; Published 6 May 2021

Academic Editor: Patrick Bednarski

Copyright (C) 2021 Quang Trung Nguyen et al. This is an open access article distributed under the Creative Commons Attribution License, which permits unrestricted use, distribution, and reproduction in any medium, provided the original work is properly cited.

\begin{abstract}
Unsymmetrical tetradentate Schiff base $\mathrm{Fe}(\mathrm{III})$ and $\mathrm{Cu}(\mathrm{II})$ complexes were prepared by the coordination of some unsymmetrical tetradentate Schiff base ligands with $\mathrm{CuCl}_{2} \cdot 2 \mathrm{H}_{2} \mathrm{O}$ or $\mathrm{FeCl}_{3} \cdot 6 \mathrm{H}_{2} \mathrm{O}$. The obtained complexes were characterized by ESI-MS, IR, and UV-Vis. The spectroscopic data with typical signals are in agreement with the suggested molecular formulae of the complexes. Their cyclic voltammetric studies in acetonitrile solutions showed that the $\mathrm{Cu}(\mathrm{II}) / \mathrm{Cu}(\mathrm{I})$ and $\mathrm{Fe}(\mathrm{III}) / \mathrm{Fe}(\mathrm{II})$ reduction processes are at (-)1.882-(-) $1.782 \mathrm{~V}$ and at (-) 1.317-(-) $1.164 \mathrm{~V}$, respectively. The in vitro cytotoxicity of obtained complexes was screened for KB and Hep-G2 human cancer cell lines. The results showed that almost unsymmetrical tetradentate Schiff base complexes have good cytotoxicity. The synthetic complexes bearing the unsymmetrical tetradentate Schiff base ligands with different substituted groups in the salicyl ring indicate different cytotoxicity. The obtained $\mathrm{Fe}$ (III) complexes are more cytotoxic than Cu(II) complexes and relative unsymmetric Schiff base ligands.
\end{abstract}

\section{Introduction}

Tetradentate salen-type Schiff bases obtained by the condensation of ethylendiamine derivatives with salicylaldehydes are attracted by many researchers because of their synthetic availability and interesting applications including catalytic, biological chemistry $[1,2]$ and coordination chemistry [3]. Transition metal complexes of tetradentate Schiff base ligands occupy a principal role in coordination chemistry for analysis, catalysis, materials science, and biochemistry [4-7]. Metallosalens are highly versatile coordination compounds with a wide range of bioinorganic and medicinal chemistry such as enzyme mimics, sensing, bioimaging, and medicinal applications [8, 9]. Some metal salen complexes have good DNA binding and RNA cleavage activity [10-12]. They have shown diverse structures and properties generating a variety of stereochemistry and bonding interactions $[13,14]$. Besides, the synthesis, characterization, and applications of symmetrical tetradentate
Schiff base complexes have been thoroughly studied and reported in the literature [15-17] recently, transition metal complexes with unsymmetrical tetradentate Schiff base ligands were reported for various applications [18-21]. Particularly, some synthetic $\mathrm{Cu}(\mathrm{II})$ and $\mathrm{Fe}(\mathrm{III})$ complexes with unsymmetrical tetradentate Schiff base ligands show potential DNA binding ability and bioactivity [22-26]. In this study, we continue to describe the synthesis, characterization, and in vitro cytotoxicity of the copper(II) and iron(III) complexes with some unsymmetrical tetradentate Schiff bases.

\section{Materials and Methods}

Analytical reagent grade chemicals such as $o$-phenylenediamine (98\%) and salicylaldehydes were obtained from Across Organics and used without any purification. All solvents were purified by following the appropriate purification procedures. 
Ultra-high performance liquid chromatography combined with hybrid quadrupole time-of-flight tandem mass spectra (UPLC-Q-TOF-MS) of the prepared unsymmetrical tetradentate Schiff base ligands were conducted on an ExionLC AC Series HPLC system coupled with a hybrid quadrupole time-of-flight tandem mass spectrometer (X500R QTOF System) equipped with Turboionspray source. Chromatographic separation was performed on a Kinetex $\mathrm{C}_{18}$ column $(30 \mathrm{~mm} \times 2.1 \mathrm{~mm}, 1.7 \mu \mathrm{m})$, and the column temperature was maintained at $30^{\circ} \mathrm{C}$. The mobile phase consisted of methanol and water containing $0.1 \%$ formic acid in gradient mode of 50\% methanol for 0-5 min and $100 \%$ methanol at $5 \mathrm{~min}$ with a flow rate of $0.3 \mathrm{~mL} \cdot \mathrm{min}^{-1}$. Electrospray ionization mass spectra $(\mathrm{m} / \mathrm{z})$ of the synthetic complexes were estimated on Agilent 6310 Ion Trap spectrometer (ESI-MS). Infrared spectra $\left(4000-400 \mathrm{~cm}^{-1}\right)$ were recorded on a Perkin Elmer Spectrum Two spectrophotometer using KBr pellet. ${ }^{1} \mathrm{H}-\mathrm{NMR}$ and ${ }^{13} \mathrm{C}$ NMR spectra were determined in DMSO- $\mathrm{d}_{6}$ solution using a Bruker Advance $500 \mathrm{MHz}$ NMR spectrometer with TMS as the internal standard and chemical shifts $(\delta)$ were recorded in ppm. UV-Visible absorption spectra of the complexes $(200-600 \mathrm{~nm})$ were measured in methanol solution $\left(2 \times 10^{-5} \mathrm{M}\right)$ on Perkin Elmer Lambda UV-35 spectrophotometer at room temperature. The effective magnetic measurements of the obtained complexes ( $\left.\mu_{\text {eff }}\right)$ were carried out at room temperature using a magnetic susceptibility balance (Mark 1, serial No. 25179) of Sherwood Scientific Ltd.

\subsection{Synthesis of Unsymmetrical Tetradentate Schiff Base} Ligands. Unsymmetrical tetradentate Schiff base ligands were prepared by one-pot method including two-step reactions similarly according to the known procedures $[27,28]$. In the first step, monocondensed half-units were prepared by the condensation of $o$-phenylenediamine with 5 - $t$-butylsalicylaldehyde or 5-methoxysalicylaldehyde. In the second step, the monocondensed half-unit was mixed with a methanol solution of relative salicylaldehydes. O-phenylenediamine $(15.5 \mathrm{mmol})$ dissolved in methylene chloride $(25 \mathrm{~mL})$ was added in a $100 \mathrm{ml}$ flask containing 5-t-butylsalicylaldehyde or 5-methoxysalicylaldehyde (15.5 mmol) and was stirred for $3 \mathrm{~h}$. After the monocondensed half-units were obtained completely by TLC checking, relative salicylaldehyde $(15.5 \mathrm{mmol})$ in methanol $(25 \mathrm{~mL})$ was added and the new mixture was stirred under ultrasound for $1 \mathrm{~h}$ more and then the productive precipitates were collected after filtered and washed by cold ethanol. The products were recrystallized from ethyl acetate and dried in vacuo.

4-(tert-butyl)-2-(E)-((2-(E)-2-hydroxybenzylidene)amino)phenyl)imino)methyl)phenol $\left(\mathrm{H}_{2} \mathrm{~L} 1\right)$ : yellow powder (72\%). Q-TOF-MS $(m / z): 373.1909 \quad[\mathrm{M}+\mathrm{H}]^{+} \quad$ (Cal.: 373.4675); IR $\left(\mathrm{KBr}, \mathrm{cm}^{-1}\right): 2967(v, \mathrm{C}-\mathrm{H}), 2748(v, \mathrm{O}-\mathrm{H})$, $1611(v, \mathrm{C}=\mathrm{N}), 1567(v, \mathrm{C}=\mathrm{C}), 1484,1369,1277(v, \mathrm{C}-\mathrm{N})$, $1186(v, \mathrm{C}-\mathrm{O}) ; 823,758(\delta, \mathrm{C}-\mathrm{H}), 506 ;{ }^{1} \mathrm{H}-\mathrm{NMR}\left(\mathrm{DMSO}-\mathrm{d}_{6}\right.$, $500 \mathrm{MHz}, \delta(\mathrm{ppm}), J(\mathrm{~Hz})): \delta 12.91$ and $12.57(\mathrm{~s}, 2 \mathrm{H}, 2 \mathrm{OH})$, 8.94 and $8.93(\mathrm{~s}, 2 \mathrm{H}, 2 \mathrm{HC}=\mathrm{N}), 7.71-7.65(\mathrm{~m}, 2 \mathrm{H}, 2 \mathrm{H}-\mathrm{Sal})$, 7.48-7.45 (m, 3H, 2H-Ph, 1H-Sal), 7.43-7.33 (m, 3H, 2H-
Ph, 1H-Sal), 6.99-6.93 (m, 2H, 2H-Sal), 6.90 (d, $J=10.0 \mathrm{~Hz}$, 1H, H-Sal), 1.29 (s, 9H, $\left.\left(\mathrm{CH}_{3}\right)_{3}\right)$; ${ }^{13}$ C-NMR (DMSO-d $\mathrm{d}_{6}$, $125 \mathrm{MHz}, \delta(\mathrm{ppm})): \delta 163.97$ and $163.83(2 \mathrm{C}, 2 \mathrm{C}=\mathrm{N}), 160.38$ and 160.31 (2C, 2C-O), 158.03 (1C, C-t-Bu), 142.47 and 142.12 (2C, 2C-Ph), 141.21 (1C, C-Sal), 133.21 (1C, C-Sal), 132.36 (1C, C-Sal), 130.60 (1C, C-Sal), 128.51 (1C, C-Sal), 127.73 and 127.55 (2C, 2C-Ph), 119.55 (1C, C-Sal), 119.41 (1C, C-Sal), 118.95 and 118.82 (2C, 2C-Ph), 116.58 (1C, C-Sal), 116.16 (1C, C-Sal), $33.74\left(1 \mathrm{C}, \mathrm{C}\left(\mathrm{CH}_{3}\right)_{3}\right), 30.96$ (3C, $\left.3 \mathrm{CH}_{3}\right)$; UV-Vis $\left(\mathrm{MeOH}, 2 \times 10^{-5} \mathrm{M}, \mathrm{nm}, \varepsilon\right): 234$ (30,000); 275 (24,500); $335(18,500)$.

4-(tert-butyl)-2-(E)-((2-(E)-5-fluoro-2-hydroxybenzylid -ene)amino)phenyl)imino)methyl)phenol $\left(\mathrm{H}_{2} \mathrm{~L} 2\right)$ : yellow powder (67\%); Q-TOF-MS $(m / z): 391.1799[\mathrm{M}+\mathrm{H}]^{+}(\mathrm{Cal}$. 391.4580); IR (KBr, cm $\left.{ }^{-1}\right): 2919(v, \mathrm{C}-\mathrm{H}), 2718(v, \mathrm{O}-\mathrm{H})$, $1615(v, \mathrm{C}=\mathrm{N}) ; 1574(v, \mathrm{C}=\mathrm{C}), 1485,1356,1264(v, \mathrm{C}-\mathrm{N})$, $1202(v, \mathrm{C}-\mathrm{O}), 821,757(\delta, \mathrm{C}-\mathrm{H}), 509 ;{ }^{\mathbf{1}} \mathrm{H}-\mathrm{NMR}\left(\mathrm{DMSO}-\mathrm{d}_{6}\right.$, $500 \mathrm{MHz}, \delta(\mathrm{ppm})): \delta 12.61$ and $12.59(2 \mathrm{H}, 2 \mathrm{OH}), 8.94$ and $8.91(2 \mathrm{H}, 2 \mathrm{HC}=\mathrm{N}), 7.69(\mathrm{~d}, J=2.5,1 \mathrm{H}, \mathrm{H}-\mathrm{Sal}), 7,53(\mathrm{dd}$, $J=9.0,3.5,1 \mathrm{H}, \mathrm{H}-\mathrm{Sal}), 7.48-7.39$ ( $\mathrm{m}, 5 \mathrm{H}, 2 \mathrm{H}-\mathrm{Sal}, 3 \mathrm{H}-\mathrm{Ph})$, $7.27(\mathrm{dt}, J=9.0,3.5,1 \mathrm{H}, \mathrm{H}-\mathrm{Ph}), 6.97$ (q, $J=4.5 \mathrm{~Hz}, 1 \mathrm{H}$, $\mathrm{H}-\mathrm{Sal}), 6.89$ (d, $\left.J=8.5,1 \mathrm{H}, \mathrm{H}-\mathrm{Sal}), 1.29\left(\mathrm{~s}, 9 \mathrm{H},\left(\mathrm{CH}_{3}\right)_{3}\right)\right) ;{ }^{13} \mathrm{C}-$ NMR (DMSO-d $\left.{ }_{6}, 125 \mathrm{MHz}, \delta(\mathrm{ppm})\right): \delta 163.89$ and 162.13 $(2 \mathrm{C}, 2 \mathrm{C}=\mathrm{N}), 158.08$ and $156.50(2 \mathrm{C}, 2 \mathrm{C}-\mathrm{O}), 155.77$ and 155.90 (1C, C-F), 142.39 (1C, C-C $\left(\left(\mathrm{CH}_{3}\right)_{3}\right), 142.14$ and 141.20 (2C, 2C-Ph), 130.61 (1C, C-Sal), 128.47 (1C, C-Sal), 127.95 and 127.56 (2C, 2C-Ph), 120.33 and 120.14 (2C, 2C$\mathrm{Ph}), 119.83$ and 119.77 (1C, C-Sal(F)), 119.52 (1C, C-Sal), 118.83 (1C, C-Sal), 118.01 and 117.95 (1C, C-Sal(F)), 116.66 and 116.47 (1C, C-Sal(F)), 116.19 (1C, C-Sal), 33.73 (1C, $\left.\mathrm{C}-\left(\mathrm{CH}_{3}\right)_{3}\right), 31.11\left(3 \mathrm{C}, 3 \mathrm{CH}_{3}\right)$; UV-Vis $\left(\mathrm{MeOH}, 2 \times 10^{-5} \mathrm{M}\right.$, $\mathrm{nm}, \varepsilon): 234$ (21,500); 275 (17,500); $340(13,500)$.

4-(tert-butyl)-2-(E)-((2-(E)-5-chloro-2-hydroxybenzylide -ne)amino)phenyl)imino)methyl)phenol $\left(\mathrm{H}_{2} \mathrm{~L} 3\right)$ : yellow powder (61\%); Q-TOF-MS $(m / z): 429.2555[\mathrm{M}+\mathrm{Na}]^{+}(\mathrm{Cal}$. 429.8941); IR (KBr, cm $\left.{ }^{-1}\right): 2952(v, \mathrm{C}-\mathrm{H}), 2697$ (br, $\left.v, \mathrm{O}-\mathrm{H}\right)$, $1614(v, \mathrm{C}=\mathrm{N}), 1567(v, \mathrm{C}=\mathrm{C}), 1486,1354,1277(v, \mathrm{C}-\mathrm{N})$; $1181(v, \mathrm{C}-\mathrm{O}), 823,757(\delta, \mathrm{C}-\mathrm{H}), 506 ;{ }^{\mathbf{1}} \mathbf{H}-\mathbf{N M R}\left(\mathrm{CDCl}_{3}\right.$, $500 \mathrm{MHz}, \delta(\mathrm{ppm})): \delta 13.09$ and $12.74(2 \mathrm{H}, 2 \mathrm{OH}), 8.64$ and $8.56(2 \mathrm{H}, 2 \mathrm{HC}=\mathrm{N}), 7.43(\mathrm{dd}, J=8.5,2.5,1 \mathrm{H}, \mathrm{H}-\mathrm{Sal}), 7.36-7.33$ (m, 4H, 2H-Ph, 2H-Sal), 7.29 (dd, $J=8.5,2.5,1 \mathrm{H}, \mathrm{H}-\mathrm{Sal}$ ), 7.24-7.22 (m, 2H, 2H-Ph), 7.00 (d, J=7.0, 1H, H-Sal), 6.98 (d, $J=7.0,1 \mathrm{H}, \mathrm{H}-\mathrm{Sal}), 1.32\left(\mathrm{~s}, 9 \mathrm{H},\left(\mathrm{CH}_{3}\right)_{3}\right) ;{ }^{13} \mathrm{C}-\mathrm{NMR}\left(\mathrm{CDCl}_{3}\right.$, $125 \mathrm{MHz}, \delta(\mathrm{ppm})): \delta 164.30$ and $162.26(2 \mathrm{C}, 2 \mathrm{C}=\mathrm{N}), 159.96$ and $159.08(2 \mathrm{C}, 2 \mathrm{C}-\mathrm{O}), 142.96\left(1 \mathrm{C}, \mathrm{C}-\mathrm{C}\left(\mathrm{CH}_{3}\right)_{3}\right), 142.03$ and 141.79 (2C, 2C-Ph), 133.09 (1C, C-Sal), 131.19 (1C, C-Sal), 131.09 (1C, 1C-Sal), 128.72 (1C, C-Sal), 128.16 and 127.60 (2C, C-Ph), 123.52 (1C, C-Cl), 119.97 (1C, C-Sal), 119.72 and 119.62 (2C, 2C-Ph), 119.16 (1C, C-Sal), 118.46 (1C, C-Sal), 117.15 (1C, C-Sal), $34.03\left(1 \mathrm{C}, \mathrm{C}\left(\mathrm{CH}_{3}\right)_{3}\right), 31.40\left(3 \mathrm{C}, 3 \mathrm{CH}_{3}\right)$; UV-Vis $\left(\mathrm{MeOH}, 2 \times 10^{-5} \mathrm{M}, \mathrm{nm}, \mathcal{\varepsilon}\right): 235(28,000) ; 276$ $(18,500) ; 335(15,000)$.

4-bromo-2-((E)-((2-(((E)-5-(tert-butyl)-2-hydroxybenz -ylidene)amino)phenyl)imino)methyl)phenol $\left(\mathrm{H}_{2} \mathrm{~L} 4\right)$ : yellow powder (56\%); Q-TOF-MS $(\mathrm{m} / z)$ : 451,1032 [M+ H] $]^{+}$ (Cal. 452.3636); IR (KBr, cm $\left.{ }^{-1}\right): 2953$ ( $\left.v, \mathrm{C}-\mathrm{H}\right), 2678$ (br, $v$, $\mathrm{O}-\mathrm{H}), 1612(v, \mathrm{C}=\mathrm{N}), 1561(v, \mathrm{C}=\mathrm{C}), 1474,1354,1276(v$, C-N), 1181 ( $v, \mathrm{C}-\mathrm{O}), 821,756(\delta, \mathrm{C}-\mathrm{H}), 507 ;{ }^{\mathbf{1}} \mathbf{H}-\mathbf{N M R}$ $\left(\mathrm{DMSO}-d_{6}, 500 \mathrm{MHz}, \delta(\mathrm{ppm})\right): \delta 13.03$ and $12.51(2 \mathrm{H}$, 
$2 \mathrm{OH}), 8.94$ and $8.91(2 \mathrm{H}, 2 \mathrm{HC}=\mathrm{N}), 7.89(\mathrm{~d}, J=2.0,1 \mathrm{H}$, H-Sal), 7.71 (d, $J=2.5,1 \mathrm{H}, \mathrm{H}-\mathrm{Sal}$ ), 7.54 (dd, $J=9.0,2.5,1 \mathrm{H}$, $\mathrm{H}-\mathrm{Sal}$ ), 7.47-7.40 (m, 5H, 2H-Ph, 3H-Sal), 6.93 (d, J=8.5, $1 \mathrm{H}, \mathrm{H}-\mathrm{Ph}$ ), 6.88 (d, J=8.5, 1H, H-Ph), 1.29 (s, 9H, $\left.\left(\mathrm{CH}_{3}\right)_{3}\right)$; ${ }^{13} \mathrm{C}-\mathrm{NMR}\left(\mathrm{DMSO}-d_{6}, 125 \mathrm{MHz}, \delta(\mathrm{ppm})\right): \delta 163.88$ and $162.14(2 \mathrm{C}, 2 \mathrm{C}=\mathrm{N})), 159.49$ and $158.01(2 \mathrm{C}, 2 \mathrm{C}-\mathrm{O}), 142.53$ $\left(1 \mathrm{C}, \mathrm{C}-\mathrm{C}\left(\left(\mathrm{CH}_{3}\right)_{3}\right), 141.80\right.$ and $141.24(2 \mathrm{C}, 2 \mathrm{C}-\mathrm{Ph}), 135.53$ (1C, C-Sal), 133.78 (1C, C-Sal), 130.65 (1C, C-Sal), 128.39 and 128.06 (2C, 2C-Ph), 127.54 (1C, C-Sal), 121.32 (1C, C-Sal), 119.60 and 119.54 (2C, 2C-Ph), 119.06 (1C, C-Sal), 118.87 (1C, C-Sal), 116.18 (1C, C-Sal), 109.72 (1C, C-Br), $33.74\left(1 \mathrm{C}, \mathrm{C}\left(\mathrm{CH}_{3}\right)_{3}\right) ; 31.11\left(3 \mathrm{C}, 3 \mathrm{CH}_{3}\right)$; UV-Vis $(\mathrm{MeOH}$, $\left.2 \times 10^{-5} \mathrm{M}, \mathrm{nm}, \varepsilon\right): 235$ (26,000); 275 (17,500); 337 (14,000).

2-((E)-((2-(((E)-2-hydroxy-3-methoxybenzylidene)ami no)phenyl)imino)methyl)-4-methoxyphenol ( $\left.\mathrm{H}_{2} \mathrm{~L} 5\right)$ : orange powder (53\%); Q-TOF-MS $(\mathrm{m} / z)$ : 377,1482 [M+ $\mathrm{H}]^{+}$ (Cal. 377.4132); IR (KBr, cm $\left.{ }^{-1}\right): 2936(v, \mathrm{C}-\mathrm{H}), 2737$ (br, $v$, $\mathrm{O}-\mathrm{H}), 1611(v, \mathrm{C}=\mathrm{N}), 1578(v, \mathrm{C}=\mathrm{C}), 1464,1364,1271(v$, C-N), $1212(v, \mathrm{C}-\mathrm{O}), 1041,818,740(\delta, \mathrm{C}-\mathrm{H}), 481 ;{ }^{\mathbf{1}} \mathbf{H}-$ NMR (DMSO- $\left.d_{6}, 500 \mathrm{MHz}, \delta(\mathrm{ppm})\right): \delta 13.30$ and 12.00 $(2 \mathrm{H}, 2 \mathrm{OH}), 8.93$ and $8.90(2 \mathrm{H}, 2 \mathrm{HC}=\mathrm{N}), 7.49(\mathrm{~m}, 1 \mathrm{H}$, $\mathrm{H}-\mathrm{Ph}), 7.43-7.38(\mathrm{~m}, 3 \mathrm{H}, 3 \mathrm{H}-\mathrm{Ph}), 7.34(\mathrm{~d}, J=3.5,1 \mathrm{H}$, H-Sal), 7.23 (dd, $J=8.0,1.0,1 \mathrm{H}, \mathrm{H}-\mathrm{Sal}), 7.10$ (dd, $J=8.0,1.5$, $1 \mathrm{H}, \mathrm{H}-\mathrm{Sal}), 7.03$ (dd, $J=9.0,3.0,1 \mathrm{H}, \mathrm{H}-\mathrm{Sal}), 6.90$ (d, $J=9.5$, $1 \mathrm{H}, 1 \mathrm{H}-\mathrm{Sal}), 6.89$ (t, $J=7.5,1 \mathrm{H}, \mathrm{H}-\mathrm{Sal}), 3.80$ (s, 3H, $\mathrm{OCH}_{3}$ ), $3.76\left(\mathrm{~s}, 3 \mathrm{H}, \mathrm{OCH}_{3}\right) ;{ }^{13} \mathrm{C}-\mathrm{NMR}\left(\mathrm{DMSO}-d_{6}, 125 \mathrm{MHz}, \delta\right.$ (ppm): $\delta 163.65$ and $162.62(2 \mathrm{C}, 2 \mathrm{C}=\mathrm{N}), 154.21(1 \mathrm{C}, \mathrm{C}-\mathrm{OH})$; 151.92 (1C, C-OH), 151.20 (1C, C-OMe), 148.00 (1C, $\mathrm{C}-\mathrm{OMe}), 142.66$ and 141.68 (2C, 2C-Ph), 127.84 and 127.63 (2C, 2C-Ph), 123.76 (1C, C-Sal), 120.82 (1C, C-Sal), 119,69 (1C, C-Sal), 119.47 (2C, C-Sal), 119.25 (1C, C-Sal), 118.33 and 117,54 (2C, 2C-Ph), 115.45 (1C, C-Sal), 114.38 (1C, C-Sal), $55.71\left(1 \mathrm{C}, \mathrm{O}-\mathrm{CH}_{3}\right), 55.54\left(1 \mathrm{C}, \mathrm{O}-\mathrm{CH}_{3}\right)$; UV-Vis $\left(\mathrm{MeOH}, 2 \times 10^{-5} \mathrm{M}, \mathrm{nm}, \boldsymbol{\varepsilon}\right): 232(27,500) ; 279(20,500) ; 340$ $(14,500)$.

2.2. Preparation of Unsymmetrical Schiff Base Complexes. Unsymmetrical Schiff base complexes were prepared from the coordination between the obtained unsymmetrical Schiff base ligands and $\mathrm{CuCl}_{2} \cdot 2 \mathrm{H}_{2} \mathrm{O}$ or $\mathrm{FeCl}_{3} \cdot 6 \mathrm{H}_{2} \mathrm{O}$ in a molecular ratio $1: 1.1 .0 \mathrm{mmol} \mathrm{CuCl} 2 \cdot 2 \mathrm{H}_{2} \mathrm{O}$ or $\mathrm{FeCl}_{3} \cdot 6 \mathrm{H}_{2} \mathrm{O}$ dissolved in ethanol was added to an ethanol solution of $1.0 \mathrm{mmol}$ ligand. The reaction mixtures were refluxed at the presence of $1.0 \mathrm{mmol} \mathrm{Na}_{2} \mathrm{CO}_{3}$ for $3 \mathrm{hrs}$; then, the reaction mixtures were cooled to room temperature. The productive precipitates were collected after filtered and washed by cold ethanol and then dried in vacuo.

[Cu(II)L1]: dark brown powder, 91\%; ESI-MS $(\mathrm{m} / z)$ : $433.9[\mathrm{M}+\mathrm{H}]^{+}(\mathrm{Cal} .434 .9) ; \mathbf{I R}\left(\mathrm{KBr}, \mathrm{cm}^{-1}\right): 2954(v, \mathrm{C}-\mathrm{H})$, $1607(v, \mathrm{C}=\mathrm{N}), 1521,1458(v, \mathrm{C}=\mathrm{C}), 1379,1257(v, \mathrm{C}-\mathrm{N})$, $1182(v, \mathrm{C}-\mathrm{O}), 1148,832,745(\delta, \mathrm{C}-\mathrm{H}), 530(\mathrm{Cu}-\mathrm{O}), 430$ $(\mathrm{Cu}-\mathrm{N})$; UV-Vis $\left(\mathrm{MeOH}, 2 \times 10^{-5} \mathrm{M}, \mathrm{nm}, \varepsilon\right): 249$ (22,500), 310 (15,500), 343 (11,500), 424 (10,000); $\mu_{\text {eff }}=1.81$ BM.

[Cu(II)L2]: pale yellow solid, 92\%; ESI-MS $(\mathrm{m} / z): 451.9$ $[\mathrm{M}+\mathrm{H}]^{+}$(Cal. 452.9); IR (KBr, cm $\left.{ }^{-1}\right): 2955(v, \mathrm{C}-\mathrm{H}), 1619$ $(v, \mathrm{C}=\mathrm{N}), 1525,1462(v, \mathrm{C}=\mathrm{C}), 1382,1258(v, \mathrm{C}-\mathrm{N}), 1179(v$, C-O), 1149, 829, $743(\delta, \mathrm{C}-\mathrm{H}), 531(\mathrm{Cu}-\mathrm{O}), 430(\mathrm{Cu}-\mathrm{N})$;
UV-Vis $\left(\mathrm{MeOH}, 2 \times 10^{-5} \mathrm{M}, \mathrm{nm}, \varepsilon\right): 249$ (25,000), 300 (18,000), 343 (13,500), 425 (10,500); $\mu_{\text {eff }}=1.97$ BM.

[Cu(II)L3]: pale yellow powder, 92\%; ESI-MS $(\mathrm{m} / \mathrm{z})$ : $467.9[\mathrm{M}+\mathrm{H}]^{+}(\mathrm{Cal} .469 .4) ; \mathrm{IR}\left(\mathrm{KBr}, \mathrm{cm}^{-1}\right): 2957(v, \mathrm{C}-\mathrm{H})$, $1616(v, \mathrm{C}=\mathrm{N}), 1524,1456(v, \mathrm{C}=\mathrm{C}), 1379,1259(v, \mathrm{C}-\mathrm{N})$, $1179(v, \mathrm{C}-\mathrm{O}), 1109,824,746(\delta, \mathrm{C}-\mathrm{H}), 538(\mathrm{Cu}-\mathrm{O}), 433$ $(\mathrm{Cu}-\mathrm{N})$; UV-Vis $\left(\mathrm{MeOH}, 2 \times 10^{-5} \mathrm{M}, \mathrm{nm}, \varepsilon\right): 250(34,000)$, 301 (20,500), $342(15,000), 425(13,500) ; \mu_{\text {eff }}=1.96$ BM.

[Cu(II)L4]: brown powder, 91\%; ESI-MS $(\mathrm{m} / z)$ : 513.9 [M $+\mathrm{H}]^{+}$(Cal. 513.9); IR (KBr, cm $\left.{ }^{-1}\right): 2962(v, \mathrm{C}-\mathrm{H}), 1617(v$, $\mathrm{C}=\mathrm{N}), 1518,1461(v, \mathrm{C}=\mathrm{C}), 1384,1257(v, \mathrm{C}-\mathrm{N}), 1172(v$, $\mathrm{C}-\mathrm{O}), 811,755(\delta, \mathrm{C}-\mathrm{H})$; $522(\mathrm{Cu}-\mathrm{O}), 427(\mathrm{Cu}-\mathrm{N})$; UV-Vis $\left(\mathrm{MeOH}, 2 \times 10^{-5} \mathrm{M}, \mathrm{nm}, \varepsilon\right): 250(28,500), 301(17,500), 342$ $(13,000), 426(11,500) ; \mu_{\text {eff }}=2.00 \mathrm{BM}$.

[Cu(II)L5]: red brown powder, 90\%; ESI-MS $(\mathrm{m} / z)$ : $437.9[\mathrm{M}+\mathrm{H}]^{+}(\mathrm{Cal} .437 .9)$; IR $\left(\mathrm{KBr}, \mathrm{cm}^{-1}\right) 2928(v, \mathrm{C}-\mathrm{H})$, $1604(v, \mathrm{C}=\mathrm{N}), 1531,1473(v, \mathrm{C}=\mathrm{C}), 1369,1222(v, \mathrm{C}-\mathrm{N})$, $1194(v, \mathrm{C}-\mathrm{O}), 1160,818,742(\delta, \mathrm{C}-\mathrm{H}), 528 \mathrm{Cu}-\mathrm{O}), 411$ $(\mathrm{Cu}-\mathrm{N})$; UV-Vis $\left(\mathrm{MeOH}, 2 \times 10^{-5} \mathrm{M}, \mathrm{nm}, \varepsilon\right): 245$ (30,500), 318 (16,500), 356 (12,500), 440 (7,500); $\mu_{\text {eff }}=1.94$ BM.

[Fe(III)L1Cl]: dark brown powder (89\%); ESI-MS $(\mathrm{m} / z)$ : 425.9 [M-Cl] $^{-}$(Cal. 426.2); IR (KBr, cm $\left.{ }^{-1}\right): 2951(v, \mathrm{C}-\mathrm{H})$, $1602(v, \mathrm{C}=\mathrm{N}), 1528(v, \mathrm{C}=\mathrm{C}), 1461,1375,1258(v, \mathrm{C}-\mathrm{N})$, $1190(v, \mathrm{C}-\mathrm{O}), 1149,813,747(\delta, \mathrm{C}-\mathrm{H}) ; 613,536(\mathrm{Fe}-\mathrm{O}) ; 475$ $(\mathrm{Fe}-\mathrm{N})$; UV-Vis $\left(\mathrm{MeOH}, 2 \times 10^{-5} \mathrm{M}, \mathrm{nm}, \varepsilon\right): 246(28,000)$, 297 (34,500), 372 (16,500), $424(10,500) ; \mu_{\mathrm{eff}}=5.98 \mathrm{BM}$.

[Fe(III)L2Cl]: red brown powder (93\%); ESI-MS $(\mathrm{m} / \mathrm{z})$ : 443.9 [M-Cl] $^{-}$(Cal. 444.2); IR $\left(\mathrm{KBr}, \mathrm{cm}^{-1}\right): 2951(v, \mathrm{C}-\mathrm{H})$, $1611(v, \mathrm{C}=\mathrm{N}), 1530(v, \mathrm{C}=\mathrm{C}), 1464,1376,1254(v, \mathrm{C}-\mathrm{N})$, $1179(v, \mathrm{C}-\mathrm{O}), 1143,828,758(\delta, \mathrm{C}-\mathrm{H}) ; 532(\mathrm{Fe}-\mathrm{O}) ; 482$ $(\mathrm{Fe}-\mathrm{N})$; UV-Vis $\left(\mathrm{MeOH}, 2 \times 10^{-5} \mathrm{M}, \mathrm{nm}, \varepsilon\right): 246(26,000)$, 297 (32,000), 375 (14,500), 427 (10,000); $\mu_{\mathrm{eff}}=5.96 \mathrm{BM}$.

[Fe(III)L3Cl]: brown solid powder (92\%); ESI-MS $(\mathrm{m} / \mathrm{z})$ : 459.9 [M-Cl] $^{-}$(Cal. 460.7); IR (KBr, cm $\left.{ }^{-1}\right): 2964(v, \mathrm{C}-\mathrm{H})$, $1610(v, \mathrm{C}=\mathrm{N}), 1527(v, \mathrm{C}=\mathrm{C}), 1453,1378,1260(v, \mathrm{C}-\mathrm{N})$, $1181(v, \mathrm{C}-\mathrm{O}), 826,760(\delta, \mathrm{C}-\mathrm{H}), 669,535(\mathrm{Fe}-\mathrm{O}), 479(\mathrm{Fe}-$ $\mathrm{N})$; UV-Vis $\left(\mathrm{MeOH}, 2 \times 10^{-5} \mathrm{M}, \mathrm{nm}, \varepsilon\right): 247$ (31,500), 297 (35,500), 375 (15,500), 424 (11,500); $\mu_{\text {eff }}=5.99$ BM.

[Fe(III)L4Cl]: brown solid powder (90\%); ESI-MS $(\mathrm{m} / z)$ : 503.9 [M-Cl] $^{-}(\mathrm{Cal} .505 .1)$; IR $\left(\mathrm{KBr}, \mathrm{cm}^{-1}\right): 2961(v, \mathrm{C}-\mathrm{H})$, $1604(v, \mathrm{C}=\mathrm{N}), 1523(v, \mathrm{C}=\mathrm{C}), 1449,1376,1258(v, \mathrm{C}-\mathrm{N})$, $1183(v, \mathrm{C}-\mathrm{O}), 824,759(\delta, \mathrm{C}-\mathrm{H}), 650,534(\mathrm{Fe}-\mathrm{O}), 476(\mathrm{Fe}-$ $\mathrm{N})$; UV-Vis $\left(\mathrm{MeOH}, 2 \times 10^{-5} \mathrm{M}, \mathrm{nm}, \varepsilon\right): 243(35,000), 304$ $(29,500), 382$ (15,500), 426 (9,500); $\mu_{\mathrm{eff}}=5.90 \mathrm{BM}$.

[Fe(III)L5Cl]: dark brown solid powder (85\%); ESI-MS $(\mathrm{m} / z): 429.9$ [M-Cl] $^{-}$(Cal. 430.2); IR $\left(\mathrm{KBr}, \mathrm{cm}^{-1}\right): 2925(v$, $\mathrm{C}-\mathrm{H}), 1599(v, \mathrm{C}=\mathrm{N}), 1533(v, \mathrm{C}=\mathrm{C}), 1461,1378,1251(v$, C-N), 1185 ( $v, \mathrm{C}-\mathrm{O}), 820,734(\delta, \mathrm{C}-\mathrm{H}), 577,535(\mathrm{Fe}-\mathrm{O})$, $415(\mathrm{Fe}-\mathrm{N})$; UV-Vis $\left(\mathrm{MeOH}, 2 \times 10^{-5} \mathrm{M}, \mathrm{nm}, \varepsilon\right): 242$ (30,000), 305 (34,500), $390(13,500), 452(8,000) ; \mu_{\mathrm{eff}}=5.94$ BM.

2.3. Electrochemical Studies. The electrochemical studies of all complexes were performed using Zahner IM6 instrument. The cyclic voltammograms of $\mathrm{Cu}$ (II) complexes and $\mathrm{Fe}(\mathrm{III})$ complexes were recorded using $1.0 \times 10^{-3} \mathrm{M}$ concentration in acetonitrile solution and $0.1 \mathrm{M} \mathrm{LiClO}_{4}$ as supporting electrolyte. The working electrode was platinum 
wire which was polished, washed, and dried. The reference electrode was $\mathrm{Ag} / \mathrm{AgCl} / \mathrm{KCl}$ and platinum wire was the counter electrode. All experiments were performed in standard electrochemical cells at room temperature at a scan rate of $100 \mathrm{mV} \cdot \mathrm{s}^{-1}$ with the potential window $-3 \mathrm{~V}$ to $+3 \mathrm{~V} v \mathrm{~s}$ $\mathrm{Ag} / \mathrm{AgCl} / \mathrm{KCl}$ reference electrode.

2.4. In Vitro Cytotoxicity. MTT (3-(4,5-dimethylthiazol-2yl)-2,5-diphenyltetrazolium) method was used to estimate in vitro cytotoxicity of obtained ligands and synthetic complexes. Human cancer cells KB and Hep-G2 were cultured in DMEM with $10 \%$ fetal bovine serum, $100 \mu \mathrm{g} / \mathrm{mL}$ streptomycin, 100 units $/ \mathrm{mL}$ penicillin, and $2 \mathrm{mmol} / \mathrm{L}$ L-glutamine at $37^{\circ} \mathrm{C}$ in a humidified atmosphere with $5 \% \mathrm{CO}_{2}$ and $95 \%$ air. Cancer cells were cultivated in 96-well plates for $24 \mathrm{hrs}$ followed by treating with different concentrations of complexes in DMSO and incubated continuously for $48 \mathrm{hrs}$ more. Then, testing cells were exposed to $10 \mu \mathrm{L}$ of freshly prepared MTT $(5 \mathrm{mg} / \mathrm{ml})$ solution and incubated for $4 \mathrm{~h}$ at $37^{\circ} \mathrm{C}$ in an atmosphere of $5 \% \mathrm{CO}_{2}$. The formazan crystals obtained during MTT incubation were dissolved in $100 \mu \mathrm{L}$ of DMSO. The absorbance was recorded at $540 \mathrm{~nm}$ on Genios TECAN spectrophotometer. The experiments were carried out in triplicate for every concentration of the complexes. The percent viable cells were plotted as a function of concentration to determine the $\mathrm{IC}_{50}$ values presented in Table 1.

\section{Results and Discussion}

3.1. Synthesis and Characterization. The unsymmetrical tetradentate Schiff base ligands $\left(\mathrm{H}_{2} \mathrm{~L} 1-\mathrm{H}_{2} \mathrm{~L} 5\right)$ (Table 2) were synthesized following a one-pot procedure in moderate yields (53-72\%) (Scheme 1) and high purity (>98.5\%) performed by UPLC (supplementary data). The obtained ligands are soluble in organic solvents such as ethanol, ethyl acetate, and dichloromethane. These compounds were characterized by Q-TOF-MS, IR, ${ }^{1} \mathrm{H}-\mathrm{NMR},{ }^{13} \mathrm{C}-\mathrm{NMR}$, and $\mathrm{UV}$-Vis spectroscopies. $\mathrm{Cu}(\mathrm{II})$ and $\mathrm{Fe}(\mathrm{III})$ complexes were prepared following the coordination of $\mathrm{CuCl}_{2} \cdot 2 \mathrm{H}_{2} \mathrm{O}$ or $\mathrm{FeCl}_{3} \cdot 6 \mathrm{H}_{2} \mathrm{O}$ with each obtained ligand in good yields $(85-93 \%)$ in ethanol (Scheme 1). The synthetic unsymmetrical tetradentate Schiff base complexes are soluble in DMSO, acetonitrile, methanol, and dichloromethane. These complexes were also characterized by ESI-MS, IR, and UVVis spectroscopies.

In the high resolution mass spectra, Q-TOF-MS, the pseudo-molecular ion signals of the obtained unsymmetrical ligands are observed as $[\mathrm{M}+\mathrm{H}]^{+}$or $[\mathrm{M}+\mathrm{Na}]^{+}$which clearly indicate molecular masses suitable for the suggested formulae. In ESI-MS spectra of synthetic complexes, pseudomolecular ion peaks are observed as $[\mathrm{M}+\mathrm{H}]^{+}$for $\mathrm{Cu}(\mathrm{II})$ complexes and $[\mathrm{M}-\mathrm{Cl}]^{-}$for $\mathrm{Fe}(\mathrm{III})$ complexes. They are quite good in agreement with the suggested formulae (Table 2).

${ }^{1} \mathrm{H}$-NMR spectra of synthetic unsymmetrical tetradentate ligands have typical signals at $13.30-12.00 \mathrm{ppm}$ for two different $\mathrm{OH}$ groups and 8.94-8.56 ppm for couples of different $\mathrm{HC}=\mathrm{N}$ groups which showed obvious evidence for unsymmetrical property of obtained ligands. There are typical signals as single signals at $1.32-1.29 \mathrm{ppm}$ for 9 protons of $\mathrm{C}\left(\mathrm{CH}_{3}\right)_{3}$ groups for $\mathrm{H}_{2} \mathrm{~L} 1-\mathrm{H}_{2} \mathrm{~L} 4$ and single signals at 3.80 and $3.76 \mathrm{ppm}$ for 2 different methoxy groups of $\mathrm{H}_{2} \mathrm{~L} 5$. In ${ }^{13} \mathrm{C}$-NMR of these tetradentate Schiff base ligands, there are also typical signals at $164.30-162.13 \mathrm{ppm}$ for two different $\mathrm{C}=\mathrm{N}$ groups, at $160.38-151.92 \mathrm{ppm}$ for two different $\mathrm{C}-\mathrm{O}$ groups. They are obvious evidences for the unsymmetrical property of synthetic tetradentate ligands. They are characteristic signals at $34.03-33.73 \mathrm{ppm}$ and $31.40-30.96 \mathrm{ppm}$ for carbon signals of $t$-Bu groups of $\mathrm{H}_{2} \mathrm{~L} 1-\mathrm{H}_{2} \mathrm{~L} 4$, at 55.71 and $55.54 \mathrm{ppm}$, for 2 different methoxy groups of $\mathrm{H}_{2} \mathrm{~L} 5$.

In IR spectra, there are typical signals for the formation of ligands at $1615-1611 \mathrm{~cm}^{-1}$ of the stretching vibrations $(v)$ of $\mathrm{C}=\mathrm{N}$ bondings. The typical signals at $2748-2678 \mathrm{~cm}^{-1}$

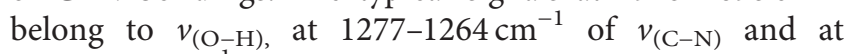
$1212-1181 \mathrm{~cm}^{-1}$ of $v_{(\mathrm{C}-\mathrm{O})}$. IR spectra of obtained $\mathrm{Cu}$ (II) complexes possess characteristic signals at $1619-1604 \mathrm{~cm}^{-1}$ of $v_{(\mathrm{C}=\mathrm{N})}$, at $1259-1222 \mathrm{~cm}^{-1}$ of $v_{(\mathrm{C}-\mathrm{N})}$, and at $1179-1148 \mathrm{~cm}^{-1}$ of $v_{(\mathrm{C}-\mathrm{O})}$. There are new signals at $538-522 \mathrm{~cm}^{-1}$ and $504-411 \mathrm{~cm}^{-1}$ for the stretching vibrations of $\mathrm{Cu}-\mathrm{N}$ and $\mathrm{Cu}-\mathrm{O}$ coordination bondings, respectively. In IR spectra of synthetic Fe(III) complexes, there are typical signals at $1611-1599 \mathrm{~cm}^{-1}$ of $v_{(\mathrm{C}=\mathrm{N})}$, at $1260-1251 \mathrm{~cm}^{-1}$ of $v_{(\mathrm{C}-\mathrm{N})}$, and $1185-1143 \mathrm{~cm}^{-1}$ of $v_{(\mathrm{C}-\mathrm{O})}$. New signals are found at $536-532 \mathrm{~cm}^{-1}$ and $482-415 \mathrm{~cm}^{-1}$ for new bonding vibrations of $\mathrm{Fe}-\mathrm{N}$ and $\mathrm{Fe}-\mathrm{O}$, respectively. The disappearance of $\mathrm{O}-\mathrm{H}$ signals and the new formation of $\mathrm{M}-\mathrm{N}$ and $\mathrm{M}-\mathrm{O}$ are the obvious evidence of the coordination of center metals with obtained ligands through the nitrogen atoms of azomethine groups and oxygen atoms of the phenolic groups (Table 3).

3.2. Electronic Spectra and Magnetic Moments. On the UVVis spectra of the obtained ligands there were three main absorption bands with maximum absorption wavelengths $\left(\lambda_{\mathrm{abs}}\right)$ at about $235 \mathrm{~nm}\left(42,553 \mathrm{~cm}^{-1}\right)$ assigned to the $\pi \longrightarrow \pi^{*}$ electronic transitions of the aromatic rings, at about $275 \mathrm{~nm}\left(36,364 \mathrm{~cm}^{-1}\right)$ and $335 \mathrm{~nm}\left(29,851 \mathrm{~cm}^{-1}\right)$ attributed to $n \longrightarrow \pi^{*}$ electronic transitions associated with the transfer of lone pair situated at $\mathrm{N}$ and $\mathrm{O}$ of $\mathrm{C}=\mathrm{N}$ and $\mathrm{C}-\mathrm{O}$ groups, respectively [25]. There is a little difference between UV-Vis spectra of these unsymmetrical tetradentate ligands $\mathrm{H}_{2} \mathrm{~L} 1-\mathrm{H}_{2} \mathrm{~L} 5$ (Figure 1). Upon complexation, $n \longrightarrow \pi^{*}$ transition of ligand shifts to a longer wavelength; this indicates the coordination of ligand to metal [26].

In UV-Vis spectra of unsymmetrical tetradentate Schiff base $\mathrm{Cu}(\mathrm{II})$ complexes, besides the main absorption bands of interligand charge transfer transitions with $\lambda_{\mathrm{abs}}$ at about 245-250 nm and 300-360 nm $\left(n \longrightarrow \pi^{*}\right)$, a new broad lowenergy absorption band with $\lambda_{\text {abs }}$ is observed at $380-500 \mathrm{~nm}$ which can be assigned to ligand-to-metal charge transfer (LMCT) and metal-to-ligand (MLCT) transitions [29, 30]. The $\mathrm{d}$-d bands were not observed due to the low concentration $\left(2 \times 10^{-5} \mathrm{M}\right)$ of the solutions. These bands should be low intensity in the region of $550-650 \mathrm{~nm}$. UV-Vis absorption bands of $[\mathrm{Cu}(\mathrm{II}) \mathrm{L} 1]-[\mathrm{Cu}(\mathrm{II}) \mathrm{L} 4]$ complexes are 
TABLe 1: In vitro cytotoxicity of the unsymmetrical tetradentate Schiff base $\mathrm{Cu}(\mathrm{II})$ complexes and Fe(III) complexes.

\begin{tabular}{lcc}
\hline Compound & & $\mathrm{IC}_{50}(\mu \mathrm{M})$ \\
& $\mathrm{KB}$ & $\mathrm{Hep}-\mathrm{G} 2$ \\
\hline $\mathrm{H}_{2} \mathrm{~L} 1$ & $>100$ & $>100$ \\
{$[\mathrm{Cu}(\mathrm{II}) \mathrm{L} 1]$} & $14.71 \pm 0.11$ & $21.04 \pm 1.08$ \\
{$[\mathrm{Fe}(\mathrm{III}) \mathrm{L} 1 \mathrm{Cl}]$} & $0.68 \pm 0.05$ & $0.83 \pm 0.05$ \\
$\mathrm{H}_{2} \mathrm{~L} 2$ & $>100$ & $>100$ \\
{$[\mathrm{Cu}(\mathrm{II}) \mathrm{L} 2]$} & $46.46 \pm 2.42$ & $18.05 \pm 0.09$ \\
{$[\mathrm{Fe}(\mathrm{III}) \mathrm{L} 2 \mathrm{Cl}]$} & $3.25 \pm 0.16$ & $7.05 \pm 0.25$ \\
$\mathrm{H}_{2} \mathrm{~L} 3$ & $80.49 \pm 0.76$ & $38.32 \pm 1.28$ \\
{$[\mathrm{Cu}(\mathrm{II}) \mathrm{L} 3]$} & $70.60 \pm 3.29$ & $35.99 \pm 0.17$ \\
{$[\mathrm{Fe}(\mathrm{III}) \mathrm{L} 3 \mathrm{Cl}]$} & $1.84 \pm 0.10$ & $6.07 \pm 0.22$ \\
$\mathrm{H}_{2} \mathrm{~L} 4$ & $>100$ & $51.08 \pm 2.42$ \\
{$[\mathrm{Cu}(\mathrm{II}) \mathrm{L} 4]$} & $85.96 \pm 4.57$ & $50.52 \pm 0.26$ \\
{$[\mathrm{Fe}(\mathrm{III}) \mathrm{L} 4 \mathrm{Cl}]$} & $2.76 \pm 0.17$ & $19.78 \pm 1.07$ \\
$\mathrm{H}_{2} \mathrm{~L} 5$ & $>100$ & $>100$ \\
{$[\mathrm{Cu}(\mathrm{II}) \mathrm{L} 5]$} & $96.71 \pm 5.11$ & $>100$ \\
{$[\mathrm{Fe}(\mathrm{III}) \mathrm{L} 5 \mathrm{Cl}]$} & $1.95 \pm 0.13$ & $2.38 \pm 0.17$ \\
Ellipticine & $1.14 \pm 0.06$ & $2.11 \pm 0.12$ \\
\hline
\end{tabular}

Table 2: Unsymmetrical tetradentate Schiff base ligands and their $\mathrm{Cu}(\mathrm{II})$ and $\mathrm{Fe}(\mathrm{III})$ complexes.

\begin{tabular}{lccccc}
\hline $\mathrm{R}^{1}$ & $\mathrm{R}^{2}$ & $\mathrm{R}^{3}$ & Ligand & $\mathrm{Cu}(\mathrm{II})$ complex & $\mathrm{Fe}(\mathrm{III})$ complex \\
\hline $\mathrm{t}-\mathrm{Bu}$ & $\mathrm{H}$ & $\mathrm{H}$ & $\mathrm{H}_{2} \mathrm{~L} 1$ & [Cu(II)L1] & [Fe(III)L1Cl] \\
$\mathrm{t}-\mathrm{Bu}$ & $\mathrm{F}$ & $\mathrm{H}$ & $\mathrm{H}_{2} \mathrm{~L} 2$ & [Cu(II)L2] & [Fe(III)L2Cl] \\
$\mathrm{t}-\mathrm{Bu}$ & $\mathrm{Cl}$ & $\mathrm{H}$ & $\mathrm{H}_{2} \mathrm{~L} 3$ & [Cu(II)L3] & [Fe(III)L3Cl] \\
$\mathrm{t}-\mathrm{Bu}$ & $\mathrm{Br}$ & $\mathrm{H}$ & $\mathrm{H}_{2} \mathrm{~L} 4$ & [Cu(II)L4] & [Fe(III)L4Cl] \\
$\mathrm{OCH}_{3}$ & $\mathrm{H}$ & $\mathrm{H}_{2} \mathrm{~L} 5$ & [Cu(II)L5] & [Fe(III)L5Cl] \\
\hline
\end{tabular}

similar except UV-Vis absorption bands of [Cu(II)L5] complex which are shifted to a longer wavelength region due to the electron-donating property of the substituted methoxy groups (Figure 2).

Magnetic measurements and electronic spectra were conducted in order to obtain information about geometry of the complexes. Copper(II) complexes, in the present study, show $\mu_{\text {eff }}$ values $1.81-2.00 \mathrm{BM}$ which were consistent with presence of one unpaired electron. This behavior suggests square-planar geometry for the copper(II) complexes $[31,32]$.

In UV-Vis spectra of unsymmetrical tetradentate Schiff base Fe(III) complexes, besides the main absorption bands with wavelength maximum at 242-247 nm, 297-305 $\mathrm{nm}$ and a shoulder at $372-390 \mathrm{~nm}$ which may be assigned to interligand charge transfer transitions $\left(n \longrightarrow \pi^{*}\right)$, there is a new broad low-energy absorption band with $\lambda_{\text {abs }}$ at $375-485 \mathrm{~nm}$ which can belong to LMCT and MLCT transitions. The $\mathrm{d}-\mathrm{d}$ bands were also not observed due to the low concentration $\left(2 \times 10^{-5} \mathrm{M}\right)$ of the solutions. While UV-Vis absorption bands of [Fe(III)L1Cl] - [Fe(III)L4Cl] complexes are similar, UV-Vis absorption bands of [Fe(III)L5Cl] complex are also moved to a longer wavelength region when it contains the electrondonating methoxy groups reasonably (Figure 3 ).

$\mathrm{Fe}(\mathrm{III})$ complexes exhibit magnetic moments of 5.90-5.99 BM due to the presence of five unpaired electrons, which indicate an octahedral geometry around Fe(III) ions $[21,25]$.
3.3. Electrochemical Studies. The electrochemical behaviors of the synthetic unsymmetrical tetradentate Schiff base $\mathrm{Cu}$ (II) and $\mathrm{Fe}$ (III) complexes were investigated using cyclic voltammetry $(\mathrm{CV})$. Cyclic voltammograms were recorded using a Zahner-elektrik IM6 instrument with a standard three-electrode setup, a platinum working electrode, a platinum wire as the counter electrode, and $\mathrm{Ag} / \mathrm{AgCl} / \mathrm{KCl}$ as the reference electrode, at room temperature with voltage scan rate $=100 \mathrm{mV} \cdot \mathrm{s}^{-1}$. The concentration of complexes in acetonitrile was $1.0 \times 10^{-3} \mathrm{M}$ and $0.1 \mathrm{M} \mathrm{LiClO}_{4}$ was used as supporting electrolyte. The cyclic voltammetric profile of synthetic $\mathrm{Cu}(\mathrm{II})$ complexes is given in Figure 4. Interestingly, the CVs of synthetic $\mathrm{Cu}(\mathrm{II})$ complexes show cathodic peaks at $(-) 1.882-(-) 1.782 \mathrm{~V}$ for the reduction of $\mathrm{Cu}(\mathrm{II}) \longrightarrow \mathrm{Cu}(\mathrm{I})$. A similar type of cathodic response was found in reported $\mathrm{Cu}(\mathrm{II})$ complexes [33]. Some slight differences in the reduction potentials of these $\mathrm{Cu}$ (II) complexes should be attributed to the effects of the electrondonating methoxy and electron-withdrawing halogen substituted groups (Table 4).

Similarly, the cyclic voltammograms of synthetic Fe(III) complexes are given in Figure 5. Synthetic Fe(III) complexes possess well-defined cathodic peaks at (-) 1.317-(-) $1.164 \mathrm{~V}$ for the reduction of $\mathrm{Fe}(\mathrm{III}) \longrightarrow \mathrm{Fe}(\mathrm{II})$ probably. A similar type of cathodic signals was observed in the reported Fe(III) complexes [34]. The reduction progresses of these Fe(III) complexes are seemingly taken easier than the ones of the $\mathrm{Cu}$ (II) complexes. Some difference in the reduction 


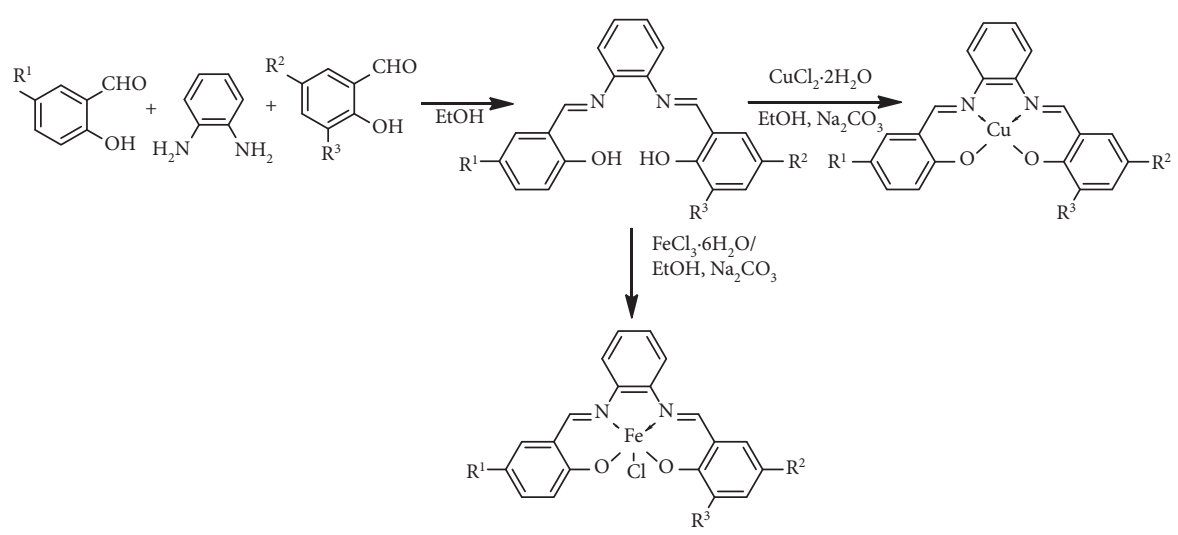

Scheme 1: Synthesis of unsymmetrical tetradentate Schiff base ligands and their $\mathrm{Cu}(\mathrm{II})$ and $\mathrm{Fe}(\mathrm{III})$ complexes.

TABLE 3: Selected typical signals of IR $\left(\mathrm{cm}^{-1}\right)$ spectra of the obtained ligands and synthetic complexes.

\begin{tabular}{|c|c|c|c|c|c|c|c|}
\hline Compound & $v_{(\mathrm{O}-\mathrm{H})}$ & $v_{(\mathrm{C}=\mathrm{N})}$ & $v_{(\mathrm{C}-\mathrm{N})}$ & $v_{(\mathrm{C}-\mathrm{O})}$ & $\delta_{(\mathrm{O}-\mathrm{H})}$ & $v_{(\mathrm{M}-\mathrm{N})}$ & $v_{(\mathrm{M}-\mathrm{O})}$ \\
\hline $\mathrm{H}_{2} \mathrm{~L} 1$ & 2748 & 1611 & 1277 & 1187 & 758 & - & - \\
\hline$[\mathrm{Cu}(\mathrm{II}) \mathrm{L} 1]$ & - & 1607 & 1257 & 1148 & 745 & 530 & 503 \\
\hline$[\mathrm{Fe}(\mathrm{III}) \mathrm{L} 1 \mathrm{Cl}]$ & - & 1602 & 1258 & 1149 & 747 & 536 & 475 \\
\hline $\mathrm{H}_{2} \mathrm{~L} 2$ & 2718 & 1615 & 1264 & 1202 & 757 & - & - \\
\hline$[\mathrm{Cu}(\mathrm{II}) \mathrm{L} 2]$ & - & 1619 & 1258 & 1149 & 743 & 531 & 504 \\
\hline [Fe(III)L2Cl] & - & 1611 & 1254 & 1143 & 742 & 532 & 482 \\
\hline $\mathrm{H}_{2} \mathrm{~L} 3$ & 2697 & 1614 & 1277 & 1181 & 757 & - & - \\
\hline$[\mathrm{Cu}(\mathrm{II}) \mathrm{L} 3]$ & - & 1616 & 1259 & 1179 & 746 & 538 & 504 \\
\hline$[\mathrm{Fe}(\mathrm{III}) \mathrm{L} 3 \mathrm{Cl}]$ & - & 1610 & 1260 & 1145 & 760 & 535 & 479 \\
\hline $\mathrm{H}_{2} \mathrm{~L} 4$ & 2678 & 1612 & 1276 & 1181 & 756 & - & - \\
\hline$[\mathrm{Cu}(\mathrm{II}) \mathrm{L} 4]$ & - & 1617 & 1257 & 1172 & 755 & 522 & 504 \\
\hline [Fe(III)L4Cl] & - & 1604 & 1258 & 1145 & 759 & 534 & 476 \\
\hline $\mathrm{H}_{2} \mathrm{~L} 5$ & 2737 & 1611 & 1271 & 1212 & 740 & - & - \\
\hline [Cu(II)L5] & - & 1604 & 1222 & 1160 & 742 & 528 & 411 \\
\hline$[\mathrm{Fe}(\mathrm{III}) \mathrm{L} 5 \mathrm{Cl}]$ & - & 1599 & 1251 & 1185 & 734 & 535 & 415 \\
\hline
\end{tabular}

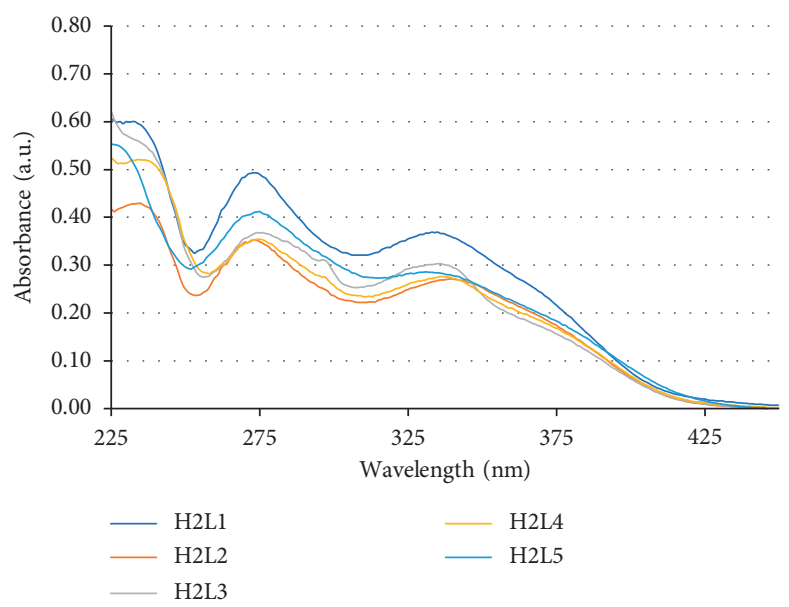

FIGURE 1: UV-Vis absorption spectra of unsymmetrical tetradentate Schiff base ligands.

potentials of the $\mathrm{Fe}(\mathrm{III})$ complexes must be expected from the electronic effects of the electron-donating and electronwithdrawing substituted groups (Table 4).
3.4. In Vitro Cytotoxicity Assay. The cytotoxicity of relative unsymmetric ligands, obtained $\mathrm{Cu}(\mathrm{II})$ complexes, and $\mathrm{Fe}(\mathrm{III})$ complexes against KB and Hep-G2 human cancer 


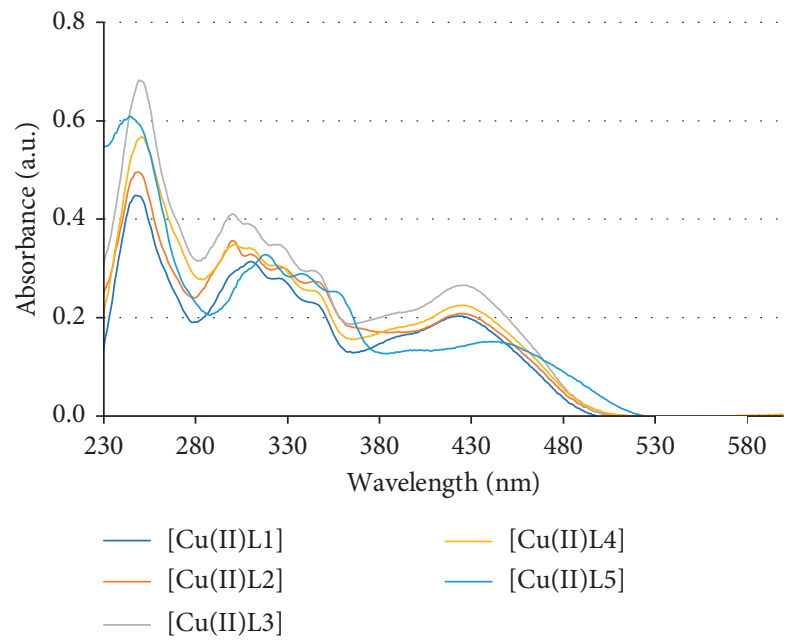

Figure 2: UV-Vis absorption spectra of unsymmetrical Schiff base $\mathrm{Cu}(\mathrm{II})$ complexes.

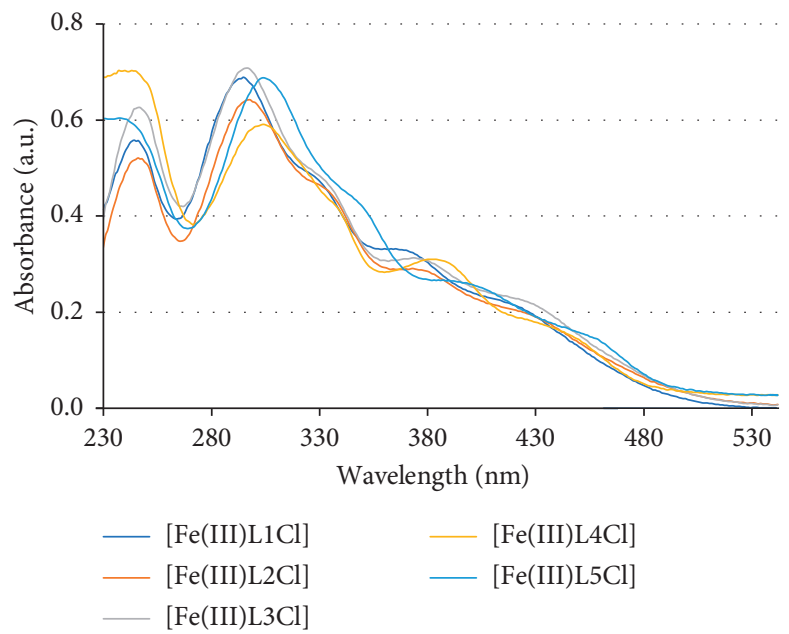

Figure 3: UV-Vis absorption spectra of unsymmetrical tetradentate Schiff base Fe(III) complexes.

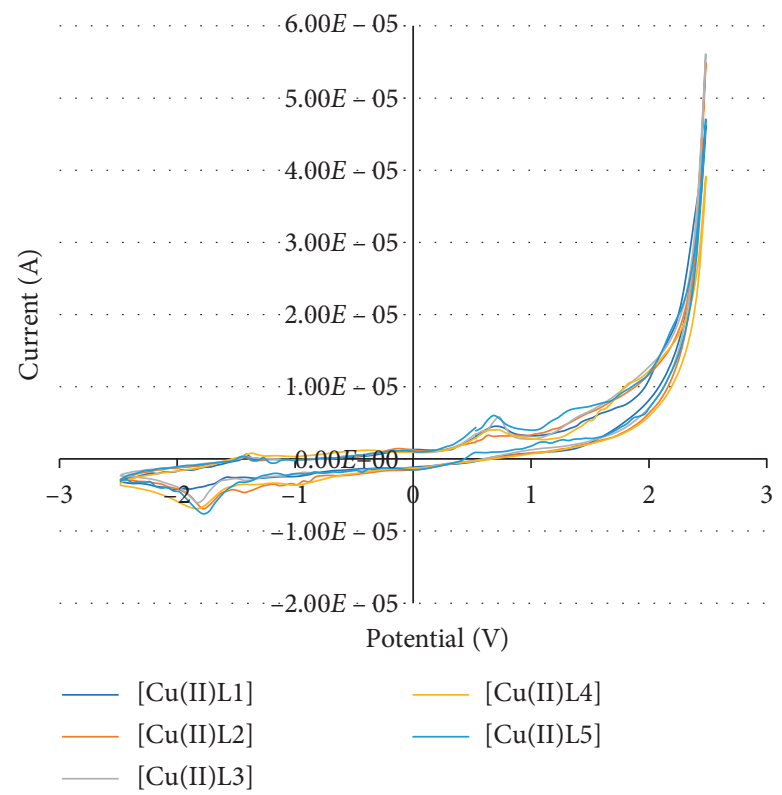

FiguRE 4: Cyclic voltammograms of unsymmetrical tetradentate Schiff base $\mathrm{Cu}(\mathrm{II})$ complexes. 
Table 4: Reduction potentials of synthetic $\mathrm{Cu}(\mathrm{II})$ and $\mathrm{Fe}(\mathrm{III})$ complexes.

\begin{tabular}{lc}
\hline Complex & Epc (V) \\
\hline$[\mathrm{Cu}(\mathrm{II}) \mathrm{L} 1]$ & -1.882 \\
{$[\mathrm{Cu}(\mathrm{II}) \mathrm{L} 2]$} & -1.782 \\
{$[\mathrm{Cu}(\mathrm{II}) \mathrm{L} 3]$} & -1.817 \\
{$[\mathrm{Cu}(\mathrm{II}) \mathrm{L} 4]$} & -1.832 \\
{$[\mathrm{Cu}(\mathrm{II}) \mathrm{L}]$} & -1.782 \\
{$[\mathrm{Fe}(\mathrm{III}) \mathrm{L} 1 \mathrm{Cl}]$} & -1.317 \\
{$[\mathrm{Fe}(\mathrm{III}) \mathrm{L} 2 \mathrm{Cl}]$} & -1.183 \\
{$[\mathrm{Fe}(\mathrm{III}) \mathrm{L} 3 \mathrm{Cl}]$} & -1.195 \\
{$[\mathrm{Fe}(\mathrm{III}) \mathrm{L} 4 \mathrm{Cl}]$} & -1.203 \\
{$[\mathrm{Fe}(\mathrm{III}) \mathrm{L} 5 \mathrm{Cl}]$} & -1.164 \\
\hline
\end{tabular}

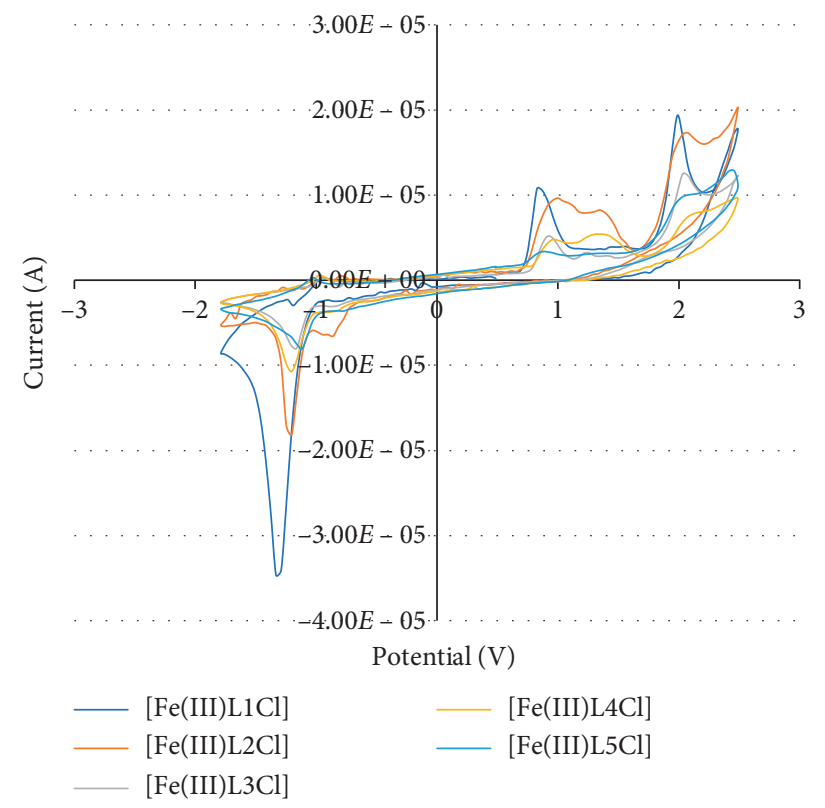

Figure 5: Cyclic voltammograms of unsymmetrical tetradentate Schiff base Fe(III) complexes.

cells was determined by MTT-dye reduction method as the standard bioassay using ellipticine as the standard compound for comparison purposes. The bioassay results are presented in Table 1.

The results showed that the synthetic $\mathrm{Cu}(\mathrm{II})$ complexes have good cytotoxicity for $\mathrm{KB}$ and Hep-G2 $\left(\mathrm{IC}_{50}<100 \mu \mathrm{M}\right)$ except $[\mathrm{Cu}(\mathrm{II}) \mathrm{L} 5]$ and better than the relative ligands. The synthetic complexes with different substituted groups possess different anticancer activity. The cytotoxic activity order of $\mathrm{Cu}(\mathrm{II})$ complexes follows as $[\mathrm{Cu}(\mathrm{II}) \mathrm{L} 1]>[\mathrm{Cu}(\mathrm{II}) \mathrm{L} 2]>$ $[\mathrm{Cu}(\mathrm{II}) \mathrm{L} 3]>[\mathrm{Cu}(\mathrm{II}) \mathrm{L} 4]>[\mathrm{Cu}(\mathrm{II}) \mathrm{L} 5]$. The obtained $\mathrm{Fe}(\mathrm{III})$ complexes have very excellent cytotoxicity for $\mathrm{KB}$ and Hep-G2 $\left(\mathrm{IC}_{50}<20 \mu \mathrm{M}\right)$, much better than $\mathrm{Cu}$ (II) complexes because Fe(III) complexes with the electrochemical reduction potentials of (-) $1.317-(-) 1.164 \mathrm{~V}$ can carry out the redox reaction easier than $\mathrm{Cu}(\mathrm{II})$ complexes with the electrochemical reduction potentials of $(-) 1.882-(-)$ $1.782 \mathrm{~V}$ probably. Fe(III) complexes exhibit an octahedral geometry around central metal ions while copper(II) complexes behave in a square-planar geometry. The cytotoxic activity order of $\mathrm{Fe}(\mathrm{III})$ complexes is [Fe(III)L1Cl] >
$[\mathrm{Fe}(\mathrm{III}) \mathrm{L} 5 \mathrm{Cl}]>[\mathrm{Fe}(\mathrm{III}) \mathrm{L} 2 \mathrm{Cl}] \sim[\mathrm{Fe}(\mathrm{III}) \mathrm{L} 3 \mathrm{Cl}]>[\mathrm{Fe}(\mathrm{III}) \mathrm{L} 4 \mathrm{Cl}]$. The substituted groups in salicyl rings have some effects to the complexes including their electrochemical properties and their bulk. [Fe(III)L1Cl] without substituted group in the second salicyl ring has the best cytotoxic activity for $\mathrm{KB}$ and Hep-G2 with $\mathrm{IC}_{50}=0.68$ and $0.83 \mu \mathrm{M}$, respectively, even better than the standard compound, ellipticine, with $\mathrm{IC}_{50}=1.14$ and $2.11 \mu \mathrm{M}$ for $\mathrm{KB}$ and Hep-G2, respectively.

\section{Conclusions}

Series of $\mathrm{Cu}$ (II) and $\mathrm{Fe}$ (III) complexes with unsymmetrical tetradentate Schiff base ligands were synthesized in good yields and characterized by ESI-MS, IR, UV-Vis, and CV spectroscopies. The characteristic spectra of ligands have changed when the coordination of the ligands to metals was carried out. The electron-donating and electron-withdrawing substituted groups of ligands have some effects on their spectral properties. The strong UV-Vis absorption bands for MLCT of the Cu(II) complexes were observed at $422-440 \mathrm{~nm}$, while the weak UV-Vis absorption bands for 
MLCT of the Fe(III) complexes were observed at 425-450 nm. The obtained copper(II) complexes with $\mu_{\text {eff }}$ values 1.81-2.00 BM show square-planar geometry for the copper(II) complexes. The Fe(III) complexes with magnetic moments of 5.90-5.99 BM indicate an octahedral geometry around $\mathrm{Fe}(\mathrm{III})$ ions. Interestingly, the CVs of synthetic $\mathrm{Cu}$ (II) complexes show cathodic peaks at (-)1.882-(-) $1.782 \mathrm{~V}$ for $\mathrm{Cu}(\mathrm{II}) \longrightarrow \mathrm{Cu}(\mathrm{I})$ reduction when the obtained $\mathrm{Fe}(\mathrm{III})$ complexes possess well-defined cathodic peaks at (-) $1.317-(-) 1.164 \mathrm{~V}$ for $\mathrm{Fe}(\mathrm{III}) \longrightarrow \mathrm{Fe}(\mathrm{II})$ reduction. The cytotoxicity in vitro for human cancer cells $\mathrm{KB}$ and Hep-G2 was estimated for synthetic $\mathrm{Cu}$ (II) complexes, Fe(III) complexes, and the relative ligands. The results showed that the synthetic $\mathrm{Cu}$ (II) complexes have good cytotoxicity for $\mathrm{KB}$ and Hep-G2 $\left(\mathrm{IC}_{50}<100 \mu \mathrm{M}\right)$ except [Cu(II)L5]. The obtained $\mathrm{Fe}$ (III) complexes have excellent cytotoxicity for $\mathrm{KB}$ and Hep-G2 $\left(\mathrm{IC}_{50}<20 \mu \mathrm{M}\right)$, much better than $\mathrm{Cu}(\mathrm{II})$ complexes and the relative ligands. Among them, [Fe(III) $\mathrm{L} 1 \mathrm{Cl}]$ showed the best cytotoxic activity for KB and Hep-G2 with $\mathrm{IC}_{50}=0.68$ and $0.83 \mu \mathrm{M}$, respectively, better than the standard compound, ellipticine with $\mathrm{IC}_{50}=1.14$ and $2.11 \mu \mathrm{M}$ for $\mathrm{KB}$ and Hep-G2, respectively.

\section{Data Availability}

The data used to support the findings of this study are included within the article and the supplementary information file.

\section{Conflicts of Interest}

The authors declare that there are no conflicts of interest regarding the publication of this paper.

\section{Acknowledgments}

This research was financially supported by Vietnam NAFOSTED, under Grant no. 104.01-2018.366.

\section{Supplementary Materials}

This section contains the spectral data of synthetic unsymmetrical tetradentate Schiff base ligands, $\mathrm{Cu}(\mathrm{II})$ and Fe(III) complexes. The spectral data of synthetic unsymmetrical tetradentate Schiff base ligands consist of UPLC, Q-TOF-MS, IR, UV-Vis, ${ }^{1} \mathrm{H}-\mathrm{NMR}$, and ${ }^{13} \mathrm{C}-\mathrm{NMR}$ spectra. The spectral data of the obtained $\mathrm{Cu}$ (II) and $\mathrm{Fe}$ (III) complexes include ESI-MS, IR, UV-Vis, and CV spectra. (Supplementary Materials)

\section{References}

[1] V. Z. Mota, G. S. G. de Carvalho, P. P. Corbi et al., "Crystal structure and theoretical studies of the keto-enol isomerism of N,N'-bis(salicylidene)-o-phenylenediamine (salophen)," Spectrochimica Acta Part A: Molecular and Biomolecular Spectroscopy, vol. 99, pp. 110-115, 2012.

[2] D. Ajloo, S. Shabanpanah, B. Shafaatian et al., "Interaction of three new tetradentates Schiff bases containing $\mathrm{N}_{2} \mathrm{O}_{2}$ donor atoms with calf thymus DNA," International Journal of Biological Macromolecules, vol. 77, pp. 193-202, 2015.
[3] J. C. Pessoa and I. Correia, "Salan vs. salen metal complexes in catalysis and medicinal applications: virtues and pitfalls," Coordination Chemistry Reviews, vol. 388, pp. 227-247, 2019.

[4] R. Golbedaghi and R. Fausto, "Coordination aspects in schiff bases cocrystals," Polyhedron, vol. 155, pp. 1-12, 2018.

[5] Y. Chen, R. Guan, C. Zhang, J. Huang, L. Ji, and H. Chao, "Two-photon luminescent metal complexes for bioimaging and cancer phototherapy," Coordination Chemistry Reviews, vol. 310, pp. 16-40, 2016.

[6] K. C. Gupta and A. K. Sutar, "Catalytic activities of Schiff base transition metal complexes," Coordination Chemistry Reviews, vol. 252, no. 12-14, pp. 1420-1450, 2008.

[7] H. Kim and Y. S. Lee, "Quantum chemical analysis of salenaluminum complexes for organic light emitting diodes," Chemical Physics Letters, vol. 585, pp. 143-148, 2013.

[8] C. Freire, M. Nunes, C. Pereira, D. M. Fernandes, A. F. Peixoto, and M. Rocha, "Metallo(salen) complexes as versatile building blocks for the fabrication of molecular materials and devices with tuned properties," Coordination Chemistry Reviews, vol. 394, pp. 104-134, 2019.

[9] A. Erxleben, "Transition metal salen complexes in bioinorganic and medicinal chemistry," Inorganica Chimica Acta, vol. 472, pp. 40-57, 2018.

[10] Z. Asadi and N. Nasrollahi, "The effect of metal and substituent on DNA binding, cleavage activity, and cytotoxicity of new synthesized Schiff base ligands and Zn(II) complex," Journal of Molecular Structure, vol. 1147, pp. 582-593, 2017.

[11] A. M. Kaczmarek, P. W. A. Porebski, T. Mortier, F. Lynen, R. Van Deun, and K. Van Hecke, "Near-infrared luminescence and RNA cleavage ability of lanthanide Schiff base complexes derived from N,N'-bis(3-methoxysalicylidene) ethylene-1,2-diamine ligands," Journal of Inorganic Biochemistry, vol. 163, pp. 194-205, 2016.

[12] P. Li, M. Niu, M. Hong, S. Cheng, and J. Dou, "Effect of structure and composition of nickel(II) complexes with salicylidene Schiff base ligands on their DNA/protein interaction and cytotoxicity," Journal of Inorganic Biochemistry, vol. 137, pp. 101-108, 2014.

[13] P. Gurumoorthy, D. Mahendiran, D. Prabhu, C. Arulvasu, and A. K. Rahiman, "Mixed-ligand copper(II) phenolate complexes: synthesis, spectral characterization, phosphatehydrolysis, antioxidant, DNA interaction and cytotoxic studies," Journal of Molecular Structure, vol. 1080, pp. 88-98, 2015.

[14] M. E. S. Serra, D. Murtinho, Z. N. da Rocha et al., "Dibrominated camphoric acid derived salen complexes: synthesis, characterization and cytotoxic activity," Polyhedron, vol. 137, pp. 147-156, 2017.

[15] S. O. Bahaffi, A. A. Abdel Aziz, and M. M. El-Naggar, "Synthesis, spectral characterization, DNA binding ability and antibacterial screening of copper(II) complexes of symmetrical NOON tetradentate Schiff bases bearing different bridges," Journal of Molecular Structure, vol. 1020, pp. 188196, 2012.

[16] S. A. Sadeek, M. S. El-Attar, and S. M. Abd El-Hamid, "Preparation and characterization of new tetradentate Schiff base metal complexes and biological activity evaluation," Journal of Molecular Structure, vol. 1051, pp. 30-40, 2013.

[17] G. Ahumada, M. Fuentealba, T. Roisnel et al., "Novel Co(II), $\mathrm{Ni}(\mathrm{II})$ and $\mathrm{Cu}(\mathrm{II})$ complexes involving a 2-thienyl and trifluoromethyl containing symmetrically-substituted tetradentate Schiff-base ligand: syntheses, structures, electrochemical and computational studies," Polyhedron, vol. 151, pp. 279-286, 2018. 
[18] I. P. Ejidike and P. A. Ajibade, "Synthesis, characterization, and in vitro antioxidant and anticancer studies of ruthenium(III) complexes of symmetric and asymmetric tetradentate Schiff bases," Journal of Coordination Chemistry, vol. 68, no. 14, pp. 2552-2564, 2015.

[19] J. Cisterna, V. Artigas, M. Fuentealba et al., "Nickel(II) and copper(II) complexes of new unsymmetrically-substituted tetradentate Schiff base ligands: spectral, structural, electrochemical and computational studies," Inorganica Chimica Acta, vol. 462, pp. 266-280, 2017.

[20] Q. Meng, J. K. Clegg, A. J. Brock, K. A. Jolliffe, L. F. Lindoy, and G. Wei, "Mono- and dinucleating $\mathrm{Ni}(\mathrm{II}), \mathrm{Cu}(\mathrm{II}), \mathrm{Zn}(\mathrm{II})$ and Fe(III) complexes of symmetric and unsymmetric Schiff bases incorporating salicylimine functions-synthetic and structural studies," Polyhedron, vol. 74, pp. 113-121, 2014.

[21] X. Liu, C. Manzur, N. Novoa, S. Celedón, D. Carrillo, and J.-R. Hamon, "Multidentate unsymmetrically-substituted Schiff bases and their metal complexes: synthesis, functional materials properties, and applications to catalysis," Coordination Chemistry Reviews, vol. 357, pp. 144-172, 2018.

[22] M. Pragathi and K. H. Reddy, "Synthesis, spectral characterization and DNA interactions of copper(II) and nickel(II) complexes with unsymmetrical Schiff base ligands," Indian Journal of Chemistry, vol. 52, no. 7, pp. 845-853, 2013.

[23] E. Sundaravadivel, G. R. Reddy, D. Manoj, S. Rajendran, M. Kandaswamy, and M. Janakiraman, "DNA binding and cleavage studies of copper(II) complex containing $\mathrm{N}_{2} \mathrm{O}_{2}$ Schiff base ligand," Inorganica Chimica Acta, vol. 482, pp. 170-178, 2018.

[24] S. Meghdadi, M. Amirnasr, M. Majedi et al., "Template synthesis, and X-ray crystal structures of copper(II) and nickel(II) complexes of new unsymmetrical tetradentate Schiff base ligands. Electrochemistry, antibacterial properties, and metal ion effect on hydrolysis-recondensation of the ligand," Inorganica Chimica Acta, vol. 437, no. 1, pp. 64-69, 2015.

[25] S. N. Shukla, P. Gaur, M. L. Raidas, and B. Chaurasia, "Tailored synthesis of unsymmetrical tetradentate ONNO schiff base complexes of $\mathrm{Fe}(\mathrm{III}), \mathrm{Co}(\mathrm{II})$ and $\mathrm{Ni}(\mathrm{II})$ : spectroscopic characterization, DFT optimization, oxygen-binding study, antibacterial and anticorrosion activity," Journal of Molecular Structure, vol. 1202, Article ID 127362, 2020.

[26] I. P. Ejidike and P. A. Ajibade, "Synthesis, characterization, antioxidant, and antibacterial studies of some metal(II) complexes of tetradentate schiff base ligand: (4E)-4-[(2-\{(E)[1-(2,4-Dihydroxyphenyl)ethylidene]amino\}ethyl)imino]pe ntan-2-one," Bioinorganic Chemistry and Applications, vol. 2015, Article ID 890734, 9 pages, 2015.

[27] K. Ambroziak and M. Szypa, "A synthesis of unsymmetrical chiral salen ligands derived from 2-hydroxynaphthaldehyde and substituted salicylaldehydes," Tetrahedron Letters, vol. 48, no. 19, pp. 3331-3335, 2007.

[28] E. J. Campbell and S. T. Nguyen, "Unsymmetrical salen-type ligands: high yield synthesis of salen-type Schiff bases containing two different benzaldehyde moieties," Tetrahedron Letters, vol. 42, no. 7, pp. 1221-1225, 2001.

[29] J. Cisterna, V. Dorcet, C. Manzur, I. Ledoux-Rak, J.-R. Hamon, and D. Carrillo, "Synthesis, spectral, electrochemical, crystal structures and nonlinear optical properties of unsymmetrical $\mathrm{Ni}(\mathrm{II})$ and $\mathrm{Cu}(\mathrm{II})$ Schiff base complexes," Inorganica Chimica Acta, vol. 430, pp. 82-90, 2015.

[30] S. Celedon, T. Roisnel, D. Carrillo, I. Ledoux-Rak, J.-R. Hamon, and C. Manzur, "Transition metal(II) complexes featuring push-pull dianionic Schiff base ligands: synthesis, crystal structure, electrochemical, and NLO studies," Journal of Coordination Chemistry, vol. 73, no. 20-22, pp. 3079-3094, 2020.

[31] V. P. Singh, S. Singh, D. P. Singh, K. Tiwari, and M. Mishra, "Synthesis, spectroscopic (electronic, IR, NMR and ESR) and theoretical studies of transition metal complexes with some unsymmetrical Schiff bases," Journal of Molecular Structure, vol. 1058, pp. 71-78, 2014.

[32] G. Ramesh, S. Daravath, M. Swathi, V. Sumalatha, D. Shiva Shankar, and Shivaraj, "Investigation on $\mathrm{Co}(\mathrm{II}), \mathrm{Ni}(\mathrm{II}), \mathrm{Cu}(\mathrm{II})$ and $\mathrm{Zn}(\mathrm{II})$ complexes derived from quadridentate salen-type Schiff base: structural characterization, DNA interactions, antioxidant proficiency and biological evaluation," Chemical Data Collections, vol. 28, Article ID 100434, 2020.

[33] K. Gutierrez, J. Corchado, S. Lin, Z. Chen, and D. M. Piñero Cruz, "A non-innocent salen naphthalene ligand and its $\mathrm{Co}^{2+}$, $\mathrm{Ni}^{2+}$, and $\mathrm{Cu}^{2+}$ metal complexes: structural, electrochemical, and spectroscopic characterization and computational studies," Inorganica Chimica Acta, vol. 474, pp. 118-127, 2018.

[34] M. V. N. Raj, K. Bhar, S. Jain, M. Rana, T. A. Khan, and A. K. Sharma, "Syntheses, X-ray structures, electrochemical properties and biological evaluation of mono- and dinuclear $\mathrm{N}_{2} \mathrm{O}_{2}$-donor ligand-Fe systems," Transition Metal Chemistry, vol. 44, no. 7, pp. 615-626, 2019. 